1 The production of the first narrative Turkish film goes back to 1916. Prior to the 1950s, the early decades of Turkish cinema had been dominated by what is known as the 'drama school tradition' that relied heavily on the theatrical adaptations of European plays.

2 Ersan llal, 'On Turkish cinema', in John D.H. Downing (ed.), Film and Politics in the Third World (New York, NY: Autonomedia, 1987), pp. 119-29, 123
3 Nilgün Abisel, Türk Sineması Üzerine Yazılar Ilstanbul: Imge, 1994), p. 106

\section{Horror of a different kind: dissonant voices of the new Turkish cinema}

\author{
ASUMAN SUNER
}

Having emerged as a popular form of entertainment in the $1950 \mathrm{~s}^{1}$ Turkish cinema's 'golden years' came during the 1960s and early 1970s. Popular Turkish cinema of this period is generally called 'Yeşilçam cinema', after the street in Istanbul where film production companies gathered. At its peak, an average of $200 \mathrm{films}$ a year were produced by Yeşilçam cinema. In 1966, Turkey was fourth in terms of world film production after the USA, India and Egypt, making 229 films. ${ }^{2}$ Turkish cinema also became very popular in other Middle Eastern countries such as Egypt, Iran and Iraq, but after this period of successful commercial growth Yeşilçam had, by the 1980s, practically died away. The prime reason for this downfall was the paradoxical situation that there had never been a truly powerful film industry in Turkey, despite the appearance of commercial vitality in popular cinema. During the heyday of Yeşilçam, commercially-minded producers invested the huge revenues that they extracted from cinema not back into the film industry but into other sectors of the economy. As a result, whilst this commercial vitality during the 1960 s and the 1970s made certain producers and stars rich, the foundations of the film industry remained vulnerable to fluctuations in the market. Amongst the developments causing substantial financial problems for producers by the mid 1970 s were the increasing production costs created by the transition to colour cinematography, political turmoil which prevented families - the traditional audience of Yeşilçam - from attending public events, and a nationwide expansion of television broadcasting. ${ }^{3}$ As a result, Turkish cinema faced a crisis during the 1980s, with an average of just ten films being produced per year. Even more discouraging was 
4 Those Turkish films that received critical international acclaim during the 1980s were not usually exhibited in Turkey due to censorship and banishment. Yol/The Way, which poses a powerful critique of Turkish society under military rule, could not be released in Turkey until the mid 1990s. Yılmaz Güney himself escaped to Europe after the 1980 military coup. Since his citizenship was revoked, he could never returned to his country and died in exile.

5 Like all classificatory categories. the distinction between 'popular' and 'art' cinemas is far from being unproblematic, for it cannot be made on the basis of unprejudiced or neutral criteria. Besides, there might be many examples which do not easily fit into either of these categories.

6 Nezih Erdoğan, 'Mute bodies, disembodied voices: notes on sound in Turkish popular cinema', Screen, vol. 43, no. 3 (2002). pp. 233-49.
7 Funda Ödemiş, 'Cameras are still rolling: making a film in Turkey', unpublished paper presented at Visions of Modernity: Cinema and Visual Culture in Turkey, University of Texas, Austin, 27-28 March 2003
8 Hamid Naficy, An Accented Cinema: Exilic and Diasporic Filmmaking (Princeton, $\mathrm{NJ}$ : Princeton University Press, 2001). p. 4. the air of demoralization that Turkish cinema had to face during the years following the 1980 military coup. In the oppressive political and social atmosphere created by the military regime, popular Turkish cinema became estranged from its traditional audience and could not keep pace with the transformation of society. Apart from a handful of 'serious' social realist films that received international critical acclaim, such as Yılmaz Güney's Yol/The Way (1982), 'the term 'Turkish film' had become a joke, synonymous with bad taste and banality.

After a decade of severe recession and crisis, the mid 1990s bore witness to a remarkable revival of Turkish cinema in two distinct areas: a new popular cinema achieving considerable box-office success, and what might be called an 'art cinema' receiving critical acclaim and awards at national and international festivals. ${ }^{5}$ The motivating force behind both modes of film production was a new generation of young directors who made their first feature films during the 1990s.

Yavuz Turgul's 1996 film Eşkiya/The Bandit is generally held to have inaugurated new popular Turkish cinema. Merging classical 'Yeşilçam' themes (love versus money; personal integrity versus material success, and so on) with a Hollywood-style presentation, The Bandit became not only a major blockbuster, but also a blueprint for future box-office success. ${ }^{6}$ Following its formula, popular Turkish films of the last decade have sought to combine technical features of contemporary Hollywood blockbusters (fast editing, mobile camera, an emphasis on action, flawless mise-en-scene, and so forth) with an ironic handling of 'Yeşilçam' themes. As for its production, the new popular Turkish cinema has generated its financial and artistic resources not so much from the film business, but from other areas of the culture industry, most notably television and advertising. Being successful professionals in the television and/or advertising sectors, the star directors of this cinema (Sinan Çetin, Yılmaz Erdoğan and others) finance their big-budget films (usually costing somewhere between US $\$ 500,000$ and US\$800,000) with the help of the revenues and business contacts generated from these sectors. ${ }^{7}$ Receiving widespread promotion and distribution in the domestic market, popular Turkish films usually achieve a considerable degree of box-office success, with audiences of between one and two million.

If popular films constitute the flamboyant side of the new Turkish cinema, what might be called 'art cinema' is a less conspicuous, but equally noteworthy, element. Two names in this category stand out as auteur directors of the new Turkish cinema due to the peculiarity of their oeuvre: Nuri Bilge Ceylan and Zeki Demirkubuz. Inspired by Hamid Naficy, the way that I use the term 'auteur' here is not intended to evoke its conventional connotations such as artistic mastery and distinguished talent; ${ }^{8}$ instead, I wish to employ the term in relation to the question of engagement with cinematic practices and social formations.

Both Ceylan and Demirkubuz made their first feature films during 
9 Demirkubuz made his first feature film, C Blok/Block $C$ in 1994, which was followed by Masumiyet/Innocence (1997). Üçüncu Sayfa/Third Page (2000). Yazgi/Fate (2001) and Itirat/Confession (2001). The three feature films that Ceylan has made so far are Kasaba/The Small Town (1998), Mayis Sikintısı/Clouds of May (1999) and Uzak/Distant (2003).

10 The preference for low budget is perceived by both Ceylan and Demirkubuz not only as a matter of finance, but rather as related to one's political and ethical positioning. In an interview, Ceylan indicates that minimalism is important for him not only in terms of budget considerations, but in terms of the use of the film medium at large. Minimalism, he argues, is his own mode of resistance to the culture of excessiveness and the craze of consumption characterizing our contemporary world. Nuri Bilge Ceylan, Mayıs Sikıntısi (lstanbul: Norgunk, 2003), p. 121. In a similar way. Demirkubuz depicts himself as a minimalist person and indicates that he would not wish to work with a bigger budget even if he had a choice. Unpublished interview conducted with Demirkubuz in Istanbul October 2002.

11 Demirkubuz himself plays the leading role in his latest film. Bekleme Odası/Waiting Room, currently in production. The film seems to have a self-reflexive story in the sense that it is about a director who is making a film adaptation of Dostoyevsky's Crime and Punishment.

12 Mehmet Emin Toprak, Ceylan's cousin and the amateur actor playing in his three films, tragically died in a car crash the day after Distant was selected for the 2003 Cannes Festival. Sharing the Best Actor award in Cannes with Muzaffer Ozdemir, the other lead in the film, Toprak became the first actor ever to win a prize in Cannes posthumously.

13 Çă̆lar Keyder and Ayşe Öncü. Istanbul and the Concept of World Cities (Istanbul: Friedrich Ebert Foundation, 1993), p. 19. the second half of the 1990s and have since developed somewhat unconventional cinematic styles, each characterized by a thematic and visual unity. ${ }^{9}$ The three feature films that Ceylan has made so far can be considered as a trilogy because of the obvious thematic continuity between the stories. Although Demirkubuz tells an independent story in each of his films, there are many self-referential allusions in the five that he has made so far. There is also a degree of self-inscription in the case of both directors that manifests itself in occasional appearances of Demirkubuz in his own films, and in the highly autobiographical tone of Ceylan's cinema. Through self-referentiality and self-inscription, Ceylan and Demirkubuz not only foreground their authorial presence within the text, they also render it problematic.

Both Ceylan and Demirkubuz adopt a small-scale, artisanal mode of production. For both directors, working with low budgets of US $\$ 50,000$ to US $\$ 100,000$ is not a matter of necessity but of preference. ${ }^{10}$ Both perform multiple roles in the process of film production, including writing, shooting, editing and acting." Both work with the same small crew, and in the case of Ceylan with nonprofessional actors including family members.

As to the question of reception, although the films by Ceylan and Demirkubuz do not do very well at the box office (partly due to their limited distribution and promotion and partly to their relative inaccessibility for ordinary audiences), they have proved to be notably successful at national and international festivals. As well as the critical acclaim and awards received at many other festivals, the two most recent films by Demirkubuz, Yazgl/Fate (2001) and İtiraf/Confession (2001), were included in the Un certain regard section of the 2002 Cannes Festival - the first time that two Turkish films received an invitation from Cannes in the same year. Similarly, Ceylan's latest film, Uzak/Distant (2003), won both the Grand Jury Prize and acting awards for its two male leads (Mehmet Emin Toprak and Muzaffer Özdemir) at the 2003 Cannes Festival. ${ }^{12}$ This was the first time since 1982 (when Güney's Yol shared the Palme d'Or with Costa Gavras's Missing) that a Turkish film received an award at the Cannes Festival.

As we witness the development of the new Turkish cinema along these two separate tracks, it is interesting to observe that despite their obvious differences there is a strong thematic continuity connecting popular and art cinemas, characterized by an obsession with the tropes of 'home' and 'belonging'. This thematic fixation can be seen as a response to a growing anxiety in Turkish society around the questions of identity and belonging following the 1980 military coup.

During the first half of the 1980s Turkey underwent a widespread implementation of neoliberal policies (privatization and deregulation), counselled by the International Monetary Fund under the patronage of the military government. ${ }^{13} \mathrm{~A}$ number of groundbreaking legal and technological reforms were also initiated in the 1980 s, particularly in the information and communications sectors, paving the way for 
Turkey's full integration into the global capitalist system. These transformations, while making it possible for certain segments of Turkish society to become fully assimilated into the globalizing world, also produced a worsening income gap and social polarization. In addition, Turkey experienced throughout most of the 1990s a protracted conflict between separatist Kurdish guerillas and the Turkish army which claimed the lives of an estimated thirty thousand people, most of Kurdish origin. As a consequence of these intensified transformations and traumatic processes, questions of belonging and identity in Turkish society have become sites of intense and conflicting emotions, manifested in the growing popularity of nationalist discourses on the one hand, and increased cynicism about, and distrust of, community relations and collective identity on the other.

This essay aims to discuss the treatment of the tropes of 'home' and 'belonging' by the two foremost auteur directors of the new Turkish cinema, Ceylan and Demirkubuz. I shall characterize these directors as the 'dissonant voices' of the new Turkish cinema in the sense that their films represent a convoluted aesthetic and political response to the problems around the questions of belonging and identity in contemporary Turkish society. I shall attempt to show that 'belonging' is treated in the films by these directors as a troubled terrain, while 'home' is rendered a prime site of the uncanny. I will focus on particular films by each director, Ceylan's Kasaba/Small Town (1998) and Mayıs Stkintısi/Clouds of May (1999) and Demirkubuz's Üçüncü Sayfa/Third Page (2000).

\section{Popular cinema and the nostalgic recovery of home}

Questions of home, belonging and identity have constituted the main thematic concerns of the new popular cinema in Turkey since the making of The Bandit in 1996. Telling the story of Baran, a Kurdish bandit who is released from prison after having served a thirty-five-year sentence, The Bandit voices a tacit critique of the rapid transformation of post-1980 Turkish society. At the beginning of the film, Baran returns to his village in Eastern Anatolia that he had left thirty-five years before, only to find it submerged under the waters of a new dam. With nothing left for him in his native village, he decides to go to Istanbul to find his relatives. On the train he meets a young man from Istanbul, Cumali, whose life revolves around nightclubs and gambling dens. Together with Cumali, Baran experiences the harsh realities of poverty, violence and alienation in Istanbul, which make him, a bandit, seem innocent in comparison. Through Baran's touching and tragicomic story, The Bandit poses the traditional values of honesty, heroism and honour represented by the ageing Kurdish bandit against the rising neoliberal values of the 1990s. Istanbul is depicted in the film as a locus of brutal capitalist relations, relentless materialism and cultural degeneration, whereas the rural East becomes the idealized site 
14 Directed by a Yılmaz Erdoğan, a popular standup comedian and television star of the 1990s, Vizontele reached cinema audiences of well over three million in Turkey on its release in 2000 .
15 For more information on Turkish nostalgia films of the 1990s, see Asuman Suner, 'Nostalgia for an imaginary home: memory, space and identity in the new Turkish cinema', New Perspectives on Turkey, no. 27 (2002), pp. 61-76. of an imaginary home. Thus the film invokes a nostalgic yearning for the period prior to the transformation of Turkish society during the last two decades.

After the enormous success of The Bandit, the nostalgic revival of the traditional modes of belonging became a prevailing thematic component in not only popular films, but also in popular television dramas of the last decade. Feudal and patriarchal relations, provincial small-town life, religious and folkloric traditions have all been reinvented as sites of collective fantasy and desire.

The nostalgic trend in popular cinema took a recent turn with Yllmaz Erdoğan's film Vizontele (2000), a film that became the largest boxoffice success in Turkish film history. ${ }^{14}$ The new nostalgic mode initiated by Vizontele is characterized by stories focusing on community life in provincial towns, usually during the 1970s prior to the 1980 military coup. Provincial town life of the past is viewed in these films through rose-tinted spectacles as a lost paradise. While the stories emphasize cordiality and the warmth of human relations from a humorous as well as a sentimental viewpoint, the mise-en-scene is dominated by aestheticized images of the rural landscape. Popular nostalgia films seem to attribute innocence, harmony and purity to traditional community relations. The story usually ends in these films at a moment when the state of euphoria is about to be irrevocably lost due to the intervention of an external force. This external force could be the construction of a dam, as in The Bandit, or the introduction of television broadcasting to a remote town, as in Vizontele. In any case, the films consistently create a sense of 'beforeness' to describe how things used to be before the intervention of an external force and the consequent deterioration of society. The intervening external force in these films can be read as an allusion to the transformation of Turkish society during the aftermath of the 1980 coup.

Popular nostalgia films are usually associated with what might be called mild leftwing oppositional politics, in the sense that they undertake an indirect critique of the transformation of Turkish society during the last two decades through an idealized representation of the 1970s. The subtle implication of these films is such that no matter how degenerated and corrupt we recently have become as a society, there is still something intrinsically good, innocent and virtuous about who we are. The source of this presumed virtue is located usually in relation to local and /or minority ethnic and religious identities, such as being of Kurdish origin. Although the films make references to minority cultures in the use of music, costumes and proper names, the question of cultural difference as an ideological and political issue is not usually openly discussed. ${ }^{15}$

Though popular nostalgia films seem to take a critical stance towards the transformation of Turkish society after the coup, they contain a kind of ideological blind spot that tames their critique. Suggesting that traditional modes of belonging in Turkish society have recently 
16 Sigmund Freud, 'The uncanny', in On Creativity and the Unconscious (New York, NY: Harper and Brothers, 1958). pp. 122-61, 149
17 lbid., p. 153

18 Barbara Creed, The Monstrous Feminine (London: Routledge, 1993). p. 54. deteriorated as an effect of the outside forces (military regime, globalization, neoliberal policies, and so on), popular films attribute an inherent virtue to what they imagine as 'home', and never actually put it under critical scrutiny.

\section{Houses of horror}

The themes of home and belonging occupy as central a place in the new art cinema of the 1990s as in its popular counterpart. Instead of preserving the presumed innocence of home by externalizing malice, however, the films reveal the deep sense of instability and angst inherent in it.

Freud's well-known concept of the 'uncanny' is employed by film studies mostly in relation to the horror genre. Seeking to explain the feeling that arouses threat and horror, Freud suggests that what we experience as 'uncanny', as opposed to our common assumptions, is 'in reality nothing new or alien, but something that is familiar and old established in the mind which has become alienated from it if only through the process of repression' ${ }^{16}$ Freud associates the ultimate experience of the uncanny with the most familiar place, the subject's former home, the womb, hence the figure of the mother. Speaking of the uncanny feeling that his male patients declare to have about female genital organs, he writes:

This unheimlich place, however, is the entrance to the former heim (home) of all human beings, to the place where anyone dwelt once upon a time and in the beginning. There is a humorous saying: 'Love is home sickness' and whenever a man dreams of a place or a country and says to himself, still in the dream, 'this place is familiar to me, I have been there before', we may interpret the place as being his mother's genitals or her body."

Psychoanalytic film theory discloses the way that the horror genre draws upon this association between the sense of 'uncanny' and the mother's body through the figure of the 'haunted house'. 'The house is haunted,' Barbara Creed writes, 'by the ghost or trace of a memory which takes the individual back to the early, perhaps foetal, relation with the womb. ${ }^{, 18}$ Here, considering the range of cases that Freud discusses in relation to the feeling of the uncanny, I suggest that the scope of the concept is not necessarily limited to a manifest sense of terror as illustrated by the horror genre, but rather includes a wider array of experiences and sensations.

The cinemas of Ceylan and Demirkubuz, in this regard, can be said to articulate a horror of a different kind. They draw upon the horrors of everyday life by exposing mundane acts of violence lurking beneath the surface of normality. The house appears as a site of the uncanny in the 
sense that it is haunted by a routine malice. Though they both invoke a sense of the uncanny in relation to home, Ceylan and Demirkubuz tell different stories in their films by using different cinematic styles.

Often compared to the neorealist mode of Iranian cinema, represented particularly by Abbas Kiarostami, Ceylan's cinema presents a peculiar blend of documentary and fiction. His films typically offer a loose account of everyday life in their slow and somewhat monotonous pace. The three feature films that Ceylan has made so far can be considered as parts of a trilogy since they tell different temporal segments of the same story, with the same characters played by his relatives. All three films revolve around the same trope: real and imagined journeys of homecoming and escape from home. Characters contemplate the possible consequences of these experiences as they observe the geographical and cultural environment surrounding them. Depicting tiny details of everyday life without seeking to reach any particular conclusion, the films simply appear to bear witness to this contemplative mode. As in the films of Kiarostami, the ordinary situations of everyday life in Ceylan's films seem to be both all too real and yet somewhat skewed and bizarre, because of the director's constant interrogation of the nature of cinematic reality.

The Small Town, Ceylan's first feature film, tells the story of three generations of a family living in a provincial town near Canakkale, a northwestern city. Shot in black and white, the film eloquently captures rhythms of nature, cycles of rural life and the daily concerns of townspeople. The sole source of tension in the narrative is a longlasting debate among family members about whether one should leave one's home town or not. Saffet, a young man in his twenties, wants to leave the town for a better life elsewhere, whereas his middle-aged uncle argues the virtues of staying in one's home town and making it a better place. The elderly father, seeming to possess the wisdom of old age, tries to ease the tension by pointing to the ironies of both positions.

The Small Town entails an autobiographical 'homecoming' journey for Ceylan himself, since he returned to his own home town to make this film which reflects upon his own childhood memories. Casting and acting further accentuate the highly autobiographical tone of the film and give it the look of a documentary. Saffet, the main character, is played by Mehmet Emin Toprak, a young factory worker and Ceylan's real-life cousin, while the elderly couple are Ceylan's own parents.

In Clouds of May, Ceylan takes a further step into his self-reflexive exploration of the theme of homecoming, and this time makes a film about the making of his previous film, The Small Town. The main character in Clouds of May, Muzaffer (Muzaffer Özdemir), is a young director like Ceylan himself, returning to his home town to make a film about it. In the first part of the film we see Muzaffer searching for locations and actors. He conducts interviews with townspeople and makes some trial shots. He has a hard time convincing his reluctant parents to play the elderly couple in the film; his father is particularly 
19 The story of Distant, Ceylan's third and the latest film, is a continuation of Clouds of May in the sense that it depicts what would happen if Saffet's dreams of leaving his home town and moving to Istanbul were to come true.
20 A straight translation of the Turkish title 'Mayıs Sıkıntısı' into English would actually be not 'Clouds of May, but 'Boredom of May'.
21 Gaston Bachelard, The Poetics of Space: the Classic Look at How We Experience Intimate Places, trans. Maria Jolas (Boston, MA: Beacon Press, 1994).

22 Ibid., p. xxxv. unwilling, not only because he finds the idea of 'acting' awkward for a man of his age, but also because he is very concerned with saving the small forest he cultivates on his property from confiscation by the authorities. Muzaffer's cousin Saffet (played by Mehmet Emin Toprak), on the other hand, willingly agrees to take part in the film, which he sees as an opportunity to leave the town and move to Istanbul with the help of Muzaffer (just like the character he plays in The Small Town $)^{19}$

In both The Small Town and Clouds of May, what constitutes the thematic and visual locus of the films is not so much 'home', but 'home town' as a geographical and cultural locality. The everyday life of townspeople mostly takes place outdoors: the countryside provides a natural playground for children after school, while patios and gardens are the places for adults to get together and chat. The landscape shots dominating both films are utterly beautiful in their plain, yet graceful rendering of nature. Despite the predominance of shots depicting lovely scenery, however, The Small Town and Clouds of May convey a strong sense of claustrophobia and immobility. 'Home town', in both films, appears as an engulfing space limiting the social horizon of its inhabitants. What lurks beneath the calm rhythm of life in the countryside is an overwhelming sense of monotony and boredom. ${ }^{20}$ The gloomy side of small-town life is expressed in both films most intensely by Saffet, Muzaffer's young cousin, who desperately seeks to make people understand that his entire life will be engraved by this provincial town unless he runs away. In The Small Town, Saffet is portrayed as a young, rebellious man who believes, contrary to the elderly members of the family who want him to find a job and get married, that he has no future in his home town, no matter what he does. In Clouds of May, Saffet appears this time as a young man who helps out Muzaffer in making a film. His main motivation in getting involved in Muzaffer's project is to find a way to escape. The beauty of the landscape that Muzaffer admires so much does not make much sense to Saffet since he can only see an unchanging environment which offers him no prospects in life. The only time that Saffet appreciates the beauty of his home town, he explains in The Small Town, is the morning that he left it to join the army. It seems that one is capable of loving one's home town only at the moment of leaving it. The same holds true for Muzaffer, and by the same token for Ceylan. Muzaffer is able to retain a positive view on his home town because he has already left it behind. To see the beauty of 'home', it seems, distance is required. 'Home', in other words, can be perceived as a 'felicitous space', in Gaston Bachelard's words, only from outside, from a distance, when it becomes a memory. ${ }^{21}$ We need the "partiality of imagination' to envisage home as a site of protection, intimacy and well-being. ${ }^{22}$ The felicitous quality of home gets lost when we get too close to it. Excessive proximity kills imagination. Home becomes an engulfing hole when one is stuck in it. 
23 Laura Mulvey, Fetishism and Curiosity (Bloomington, IN: Indiana University Press, 1996). p. 12.
What haunts 'home' in Ceylan's films, then, is not only the condition of boredom and monotony, but also excessive proximity. Ceylan's camera meticulously searches for the minuscule details of everyday life that convey this sensation. One such detail is captured in the extreme closeup shots of the faces and bodies of the characters. On one occasion, for example, we see the feet of Ceylan's mother in a lengthy closeup shot. Lying down on a couch, the elderly woman complains to her husband about the itchiness that prevents her from sleeping at night, as the camera shows in closeup one foot rubbing against the other. The situation is very familiar and ordinary. The mother suffers from a minor health problem and disagrees with her husband about the source of it. She thinks that it is hereditary, while the husband claims that it is because of the heavy food that she is in the habit of eating. Throughout this argument, the camera continues to show the mother's bare, worn-out feet. What produces an uncanny effect throughout this scene is precisely the excessive familiarity of the image. What comes as a shock, in other words, is the way that the camera positions the audience in a condition of excessive proximity with what is all too familiar, the mother's body. It is interesting to note that the female foot is one of the favourite fetish objects in cinema. If fetishism is primarily based on the repression of the mother's body, ${ }^{23}$ the bare feet of Ceylan's mother in this scene, far from being turned into a fetish object, seem to expose what fetishism seeks to disavow.

Home as a site of the uncanny is also invoked by the visual metaphors that Ceylan employs in his films. One such recurring visual motif in both The Small Town and Clouds of May is the image of a turtle. In Clouds of May Muzaffer is very much interested in filming turtles, while in The Small Town the image of the turtle turns into a symbol. Towards the beginning of the film, we see a little sister and brother (the grandchildren of the family) wandering around the meadows after school. At one point, the little boy sees a turtle on the ground and begins to watch it. His sister explains that if a turtle is placed upside down, it will die since it cannot turn over onto its feet again. After a while, they walk away. A few minutes later, the small boy runs back and, after a moment's hesitation, turns the turtle upside down. At night, the image of the upturned turtle returns to haunt him in his dreams. When family members subsequently get together in the small forest for a picnic, the little boy falls asleep on his mother's knees. In a dream sequence, he first sees the worried face of his mother looking through a window, then the image of the upturned turtle desperately moving its legs. The next image is again that of the mother on her knees performing namaz (the Islamic ritual of worship). The boy then sees himself asleep in his bed, as his mother looks through the bedroom window. He wakes up in the dream and sees his mother lying in a strange position (reminiscent of the one taken in namaz) on the platform at the edge of the window. The woman appears to bend down on her body, pulling her legs and arms near to her head as though she 
The dream sequence in The Small Town (Nuri Bilge Ceylan, 1998)

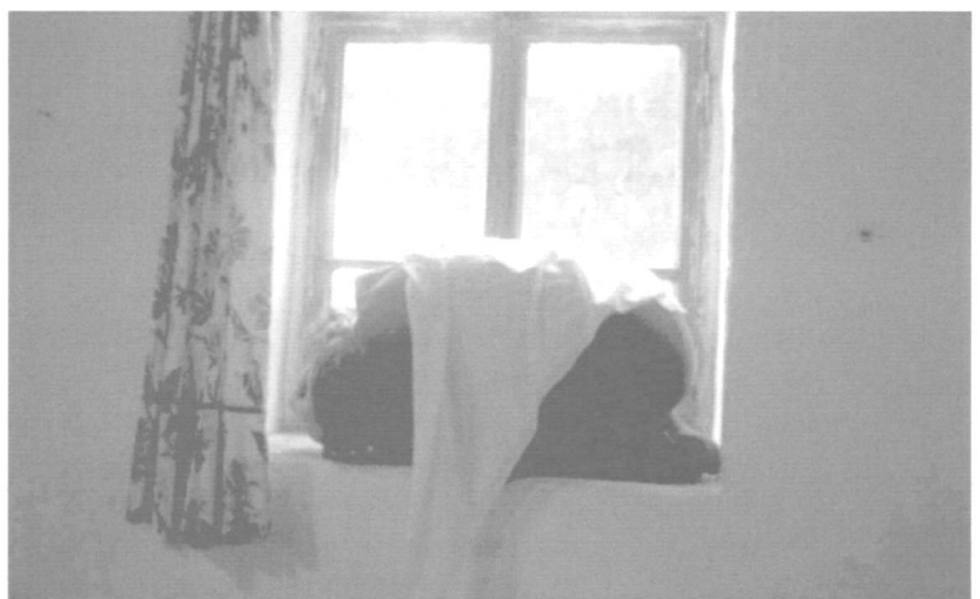

wants to cover herself up. The curved profile of the figure resembles that of a turtle. The boy gets scared in the dream and begs his mother to get off the platform but the woman's body falls from it. The final image of the dream, or nightmare, sequence is that of the upturned turtle desperately trying to move.

The image of the turtle in The Small Town is articulated into different layers of meaning. For one thing, the turtle symbolizes home in Turkish culture, since it is known as an animal carrying its house on its back. The turtle not only carries its house, however, but is completely confined by it. The turtle's house is a prison house; the turtle actually is its house. Then, even when it is not upturned, the turtle is captured in its own house, captured by itself. Seen in this way, the turtle as a symbol perfectly embodies the comforting as well as the uncanny side of belonging. What protects and comforts also captures and imprisons. Belonging is a kind of shelter and a baggage that the subject cannot possibly be rid of.

Aside from these implications, what is also interesting is the return of the tormented turtle in the boy's dream. The little act of cruelty remains totally unexplained and unresolved. There is nothing in the story that provides a logical explanation for such an act. This little 'innocent' malice, which seems to be a result of a momentary impulse of curiosity and viciousness, deeply disturbs the seemingly calm and peaceful mood of the film. The association of the image of an upturned turtle with the mother's body appears to be a reminder of something irreducibly uncanny about belonging.

Ceylan's cinema locates the sources of the uncanny experience in the normality of everyday life. Home, with all its familiarity and intimacy, could be an engulfing space, a site of 'harmless' horror. The kind of horror that haunts home in Ceylan's cinema is not something that could be externalized or resolved, it is inscribed rather in the very idea of belonging.

Ceylan's highly subjective contemplation on the theme of 
24 Unpublished interview, conducted in Istanbul, October 2002. homecoming finds its reverse counterpart in Demirkubuz's cinema in the covert theme of homelessness. Demirkubuz's films revolve around journeys of entrapment in a social labyrinth, where the characters are constantly on the move without going anywhere. Unlike Ceylan's open-ended documentary style, Demirkubuz's cinema is based on tightly structured plots with melodramatic overtones. His films revolve around highly agitated characters captivated by harsh social and/or economic realities, and he describes his characters as 'disempowered, entrapped and weak' ${ }^{24}$ They are caught up in situations from which there is no way out. They do not feel at home anywhere in the world, neither in the place that they inhabit, nor in their own identities and bodies. The prevailing mood in Demirkubuz's films is that of despair enveloped by a dark sense of irony. As opposed to the ordinary situations of everyday life depicted by Ceylan, Demirkubuz's films always draw upon highly dramatic and violent events often involving murder and/or suicide.

The desperate mood arising from the condition of entrapment in Demirkubuz's films is visually conveyed in the mise-en-scene through the excessive use of claustrophobic interiors. Events usually take place in gloomy apartments or hotel rooms that are all alike. In those rare instances when urban space is shown, all the signs demarcating the specificity of space are effaced to an extent that the city becomes unrecognizable as a particular locality. As a result, whether shot in a small city or in Istanbul, all the outdoor shots in Demirkubuz's films somehow reproduce the dull and gloomy atmosphere of an anonymous provincial town.

Demirkubuz's 2000 film Third Page takes its title from the type of news typically appearing on page three of Turkish dailies - domestic abuse, 'crimes of passion', and so forth. Although it is set in Istanbul, the film does not reflect in the slightest the historical and geographical sights of that spectacular city. Instead, most of the story takes place in the gloomy atmosphere of the basement apartment of its main character. Third Page tells the story of Isa (Ruhi Sarı), a television extra, who is beaten up and threatened by a gangster over fifty dollars that he is supposed to have stolen. Back at Isa's basement apartment, as he prepares to blow out his brains in desperation, Isa's landlord suddenly shows up to demand his back rent. In the throes of a nervous breakdown, Isa follows the landlord to his apartment, shoots him dead and then himself passes out. On waking, he is surprised to find himself back in his own apartment. Taking Isa's testimony along with that of the other tenants, the police are unable to solve the case and do not charge anyone with murder. Meanwhile Isa is befriended by his nextdoor neighbour Meryem (Başak Köklükaya), a charming young woman who lives with her children and abusive husband. Soon Isa falls in love with Meryem and cannot bear overhearing her screams and cries as she suffers at the hands of her husband every night. One day, Meryem asks Isa to kill her husband. Upset by his hesitance, she implies that she 
knows he has already killed someone else. When Isa forces her to tell what she knows, Meryem, in a lengthy monologue, confesses that she has been the landlord's mistress for years due to a tacit agreement he had with her husband. She was sexually exploited and abused by both men. On the night that Isa shot the landlord, Meryem explains, she was in his apartment, saw what happened and destroyed all the evidence implicating Isa. Later in the film, it turns out that Meryem actually has a different love, the landlord's son, and she manipulates Isa to get rid of her husband.

The intricate story of Third Page consists of many layers. The plot clearly echoes the film noir genre, with a femme fatale at its centre and a deceived man who falls into a trap when trying to help an attractive and mysterious woman. This odd adoption of the noir genre into an unlikely social context becomes further complicated by the religious overtones produced by the names of the main characters. Isa and Meryem, in Turkish, are proper names denoting Christ and the Virgin Mary. Giving such culturally loaded names to the characters involved in an intricate plot of murder and adultery, the film foregrounds existential questions about fate, responsibility and sin, the favourite themes of Demirkubuz, a director deeply influenced by Dostoyevsky. ${ }^{25}$ What is more significant for our discussion here, however, are the self-referential allusions and the sense of repetition in Third Page.

Prison is one of the recurring motifs in Demirkubuz's cinema. It appears in his films, however, not so much as a physical space but as a metaphor for the way that the characters perceive the space that they inhabit. Demirkubuz's 1996 film Masumiyet/Innocence, for example, opens in a prison where the main character, an inmate who has just completed his sentence, tries to explain why he does not want to be released but to spend the rest of his life at the prison. The opening sequence, though it supposedly takes place in the actual space of the prison, does not contain any visual signifiers of imprisonment such as bars or cells. When the main character steps into the outside world, however, he is repeatedly portrayed behind bars or within cell-like rooms. The same trope is repeated in Demirkubuz's 2000 film Yazgl Fate, in which the main character, although convicted for a crime that he did not commit, does not care about proving his innocence since he feels that there is no difference between prison and the outside world.

In Third Page, the trope of prison arises in relation to the representation of home. Stripped of all of its romantic connotations, home is represented in the film as a place of confinement, a prison that houses horrific acts of violence. Again and again, Meryem refers to her basement apartment as a wretched place of imprisonment. Seeing herself as someone entangled in poverty and abuse, she is totally disillusioned with her life. She perceives the physical space of her basement flat as the materialization of the harsh realities that make her life a prison. When asked to make a choice between the two men abusing her, she explains she would choose the landlord since his 
apartment is larger and more comfortable than her husband's basement flat. At the end of the film, when Isa finds her in the apartment of her secret lover, the landlord's son, she emphasizes that men do not make much difference, but what matters now is that she lives in a much better place.

Home is quite directly associated with horror in Third Page. Though Meryem's small basement apartment looks rather normal and ordinary, there is something unmistakably eerie about it. This eerie element does not so much arise from the violence that openly goes on in the house, but the way that it is normalized and rendered invisible. Although all the tenants know of the horrific events that take place in the flat, they tend to behave as if nothing has happened. Neither the bruises on Meryem's face nor her screams seem to be noticed by anyone.

Everyone in the film is not only complicit in violence, but also capable of inflicting it. Talking about the details of the murder plan that she concocts for her husband, for example, Meryem sounds like a housewife giving a recipe. When Isa hesitates, she calmly says she would not mind doing a dirty job like slashing the man's face - horror turns into a domestic affair.

What creates the dark and deeply pessimistic tone of Demirkubuz's cinema is the sense of compulsive repetition in his films, which creates the impression that characters are stuck in a labyrinth from which they cannot possibly escape. In a confined world where there seems to be no way out, everything perpetually replicates itself. All the relations are the same; time and again, similar situations occur between different people. Even when the characters attempt to do things differently, they always end up in the same vicious circle. No matter how hard they try to make a difference, everything remains the same.

The uncanny feeling, Freud explains, is related also to the idea of doubling that may occur through the recurrence of similar situations, things and events. An involuntary return to the same situation results in a feeling of helplessness and a sense of the uncanny. A recurrent theme in dreams, for example, is when one is lost in a forest or in the mist and every endeavour brings you back to the same spot. 'It is only this factor of involuntary repetition', Freud writes, 'which surrounds with an uncanny atmosphere what would otherwise be innocent enough, and forces upon us the idea of something fateful and inescapable where otherwise we should have spoken of chance only'. ${ }^{26}$

The sense of compulsive repetition in and across Demirkubuz's films can be said to create an abyss that fosters an uncanny sensation. Characters seem to know that their every endeavour will bring them back to the same spot. The claustrophobic structure of the mise-enscene further contributes to a sense of involuntary repetition. All spaces resemble one another. The houses depicted in the films are designed to create a sense of uniformity and repetition. Demirkubuz's cinema, in this regard, can perhaps be described as a horror cinema undercover. 
27 Nikos Papastergiadis, Dialogues in the Diasporas: Essays and Conversations on Cultural Identity (London: Rivers Oram Press, 1998). p. 3.
28 Mary Ann Doane, 'The voice in cinema: the articulation of body and space', in Bill Nichols (ed.). Movies and Methods Volume II: an Anthology (Berkeley, CA: University of California Press, 1985), pp. 565-75.

29 Kaja Silverman, The Acoustic Mirror: the Female Voice in Psychoanalysis and Cinema (Bloomington, IN: Indiana University Press, 1988), p. 45 30 Ibid., p. 45.
31 Naficy, An Accented Cinema p. 121
What makes his films disturbing is the way that horror is turned into something so banal and ordinary that it is no longer recognized as such.

As opposed to the popular nostalgia films of the last decade which focus on situations where home is threatened from outside, the films by Ceylan and Demirkubuz focus on situations where home is challenged from within. 'We can always defend ourselves or even rebuild after the home has been attacked from outside', Nikos Papastergiadis writes, 'but how do you deal with the slow but determined process of implosion? What happens when our sense of home is filled with trauma? ${ }^{27}$ The cinema of Ceylan and Demirkubuz seems to describe this slow, but determined process of implosion.

\section{Dissonant voices}

In the films of Ceylan and Demirkubuz, sound is not used to complement the image and enhance the illusion of reality, but instead as a dissonant element which disorients the audience and serves to problematize the possibility of retaining a smooth sense of belonging and identity. Film theory maintains that the rule of synchronization, the smooth alignment of the human form with the human voice, is central to mainstream narrative cinema. The conventions of sound reproduction, according to Mary Ann Doane, together with classical techniques of invisible editing and narrative transparency, work to create the illusion of a unified source of audiovisual information. ${ }^{28}$ In this way, the text demonstrates a sense of self-sufficiency in which images and sounds seem to be generated internally by the fictional world of the film, and not constructed externally. In a similar vein, Kaja Silverman explains how the sonic regime of dominant cinema contains the human voice within the fiction of diegesis. ${ }^{29}$ This is accomplished through the use of synchronization 'which anchors sounds to an immediately visible source, and which focuses attention upon the human voice and its discursive capabilities' ${ }^{30}$

Synchronization, in this context, just like the shot/reverse-shot formation, helps to suture the spectator to the story and direct attention away from the site of cinematic production.

The smooth alignment of sound and image also fosters the reality effect that the mainstream cinema seeks to create. The voice serves as a guarantor of the authenticity and the presence of the person that it belongs to. The body, in other words, is assumed to 'house' the inner truth (the soul) of the subject which finds its expression through the voice. The voice coming out of the body testifies to the authenticity of the speech. As Hamid Naficy points out, there exists 'a unique relationship between voice, interiority and identity', since speech and voice are typically associated with proximity and presence..$^{31}$ For that reason, according to Naficy, the use of nonalignment of speaker and voice would be a counter-hegemonic cinematic strategy that serves to complicate the notions of belonging and identity. 
In Ceylan's cinema, sound is transformed into a dissonant element mostly as a result of the insertion of multiple layers of reality into the narrative. Asking 'real' people (his parents and relatives) to act themselves, Ceylan not only creates an odd sense of intimacy with 'reality' in his films, but he also subjects everything to a double-erasure by constantly disclosing the performative aspect of what is presumed to be 'real'. In Clouds of May, there are several interesting instances illustrating how the fine line between 'being oneself' and 'acting oneself' is relentlessly blurred by Ceylan. Towards the end of the film, for example, when Muzaffer finally manages to convince his reluctant parents to play the elderly couple in his film, the entire family goes to the small forest for an afternoon shoot. (The scene that they shoot turns out to be a segment of the final sequence of The Small Town in which family members spend an evening together in the forest cultivated by the father.) During the shoot, Muzaffer is positioned behind the camera while his assistant Sadık arranges lighting with a reflector and Saffet acts as prompt. The father is positioned in front of the camera, seated under a large tree. After the 'action' command from Muzaffer, the camera runs and the father repeats the lines, prompted by Saffet: 'Well ... / Here I am. / Now I earn my living as a farmer. / What difference does it make? / Nothing matters. / But, then, neither do I want to die. / If God allows, I want to live for at least another twenty years.' An external voice (spoken by Sadik) asks: 'Is it raining?' The father looks up and replies by following the lines prompted by Saffet again: 'What? / Is it raining? / I don't think so.' After the shooting, Muzaffer warns his father to be more careful and not to be late in looking up to see whether it is raining. He complains that his father's acting is not good enough. The scene is repeated. This time, however, Muzaffer becomes even more upset. He accuses his father of making long pauses between the lines. He reminds him that ten million Turkish liras is wasted in each shoot. The father takes this warning quite seriously since he is daunted by the amount of money being spent and promises to be more careful. Muzaffer scolds others as well. He alerts Saffet not to give long pauses in prompting. After a small family squabble, they once again begin filming. This time, however, Saffet reads the script so fast that the father cannot follow. Muzaffer yells at Saffet. The father gets upset about the loss of another ten million liras. Muzaffer alerts everyone once again to be more careful and the scene is repeated. Everything seems to go all right this time; the father completes his lines correctly. At the end, however, when the external voice asks 'is it raining?', the father looks up, and instead of saying his lines, keeps looking up silently. Muzaffer loses his temper and starts yelling at his father: 'What happened this time father? Why didn't you say your lines?' Still looking up at the tree, the father slowly stands up without saying anything. When the camera shows where he is looking, it becomes clear that there is a red mark on the tree indicating that it has been confiscated by the authorities. It turns out that while the family 
Muzaffer (Muzaffer Özdemir) films

Saffet (Mehmet Emin Toprak) in Clouds of May

(Nuri Bilge Ceylan, 1999)
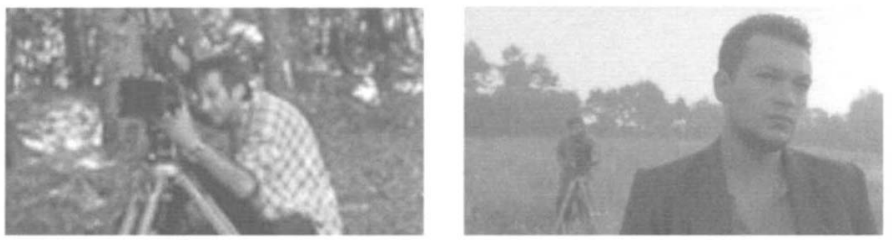

were away filming for the last couple of days, the authorities came in and marked the entire forest for confiscation.

The ironic tone of this scene arises from the awkwardness of the situation that it depicts. Filmmaking, an activity usually associated with intellectual and artistic production, is transformed into a highly domesticated and humble practice here. An ordinary elderly man, preoccupied by some very concrete problems in his real life, is made by his son to act in a movie, a job that he perceives not only as an unnecessary disruption, but also as trivial and ridiculous. The irony also arises from the bizarre condition of 'acting oneself'. Muzaffer asks his father to be 'natural', to be just like himself. This seemingly easy task, however, proves to be quite tricky in practice, as the father seems to be incapable of giving a 'natural' performance as himself. Having said that, as we watch the scene we also know that what is presented as an unsuccessful performance is already a successful one, because the father is actually supposed to give a performance of failing to perform himself. In other words, what appears to be 'natural' in the scene, the father's failure in performing himself, is already a successful performance. Different layers of reality in the scene are made manifest by the dissociation of voice and person. The words that actually belong to the father are prompted by an external voice. Such a dissociation of voice and person serves to destabilize the assumptions about having a smooth and self-integrated identity. As the unity of the body and the voice is interrupted, self-revelation becomes something dictated from outside.

Sound is transformed into a dissonant element in Third Page in a less playful and more disorienting way. As I demonstrated above, Third Page, like Demirkubuz's other films, is dominated by an exceedingly claustrophobic visual atmosphere. Most scenes in the film are shot in barely lit, gloomy interiors. The intense sense of claustrophobia, however, is not solely generated by mise-en-scene, but more effectively by the use of sound. Almost all the scenes in Third Page are dominated by a loud and annoying background noise. In the opening sequence of the film, as we see Isa brutally beaten up by the gang leader, we hear in the background the loud voice of a television sports commentator describing a football game. In the following scene, Isa goes to try to look for some money at the studio where he works. As he desperately tries to explain the situation to his rude and ignorant boss, in the background we see and hear the shooting of a mafia murder scene for a television drama. When Isa first goes to Meryem's apartment, they chat 
a little at the breakfast table while a loud debate is going on in a daytime television talk show in the background. Later in the film, Isa cannot get any sleep at nights since he is forced to listen to the violent arguments between Meryem and her husband. Even the quietest scenes of Third Page include the sound of either television or heavy traffic in the background.

The characters' experience of entrapment and captivity in Third Page, then, is emphasized by the claustrophobic atmosphere created by the ubiquitous presence of sound in the film. The pervasive sense of helplessness and confinement that the film conveys arises from the condition of being continuously surrounded by fragments of absurd and violent pieces of discourse. The characters are constantly under surveillance, constantly being terrorized. They cannot have a single quiet moment to reflect upon their own condition. Their own voices are swallowed up by the fragments of senseless discourse surrounding them. Apart from this constant disruptive effect of sound, there is a particular instance in Third Page in which the transformation of discourse into an alien and invading element is illustrated in a particularly revealing way. This is Meryem's confession scene.

Monologue is a dominant narrative element in Demirkubuz's cinema. In all of his films, the flow of events is interrupted at a certain point by a lengthy confessional monologue in which some dark secrets are revealed. Monologue scenes usually represent some kind of a halt in the story that momentarily immobilizes the narrative progress. The mise-en-scene employed - the characters typically positioned side by side in a medium-shot facing the camera and not each other - creates the impression that the confessing character does not speak to another character in the diegesis but directly addresses the audience. The lengthy monologue scene in Third Page creates such an effect. Throughout this scene, which lasts approximately six minutes, Meryem is depicted in a series of medium closeup shots, narrating her story in a somewhat monotonous way with her eyes fixed on a point on the floor. Although she cries as she speaks, her tone of voice is distant and blank.

Meryem's (Basak Köklükaya) monologue in Third Page (Zeki Demirkubuz, 2000).

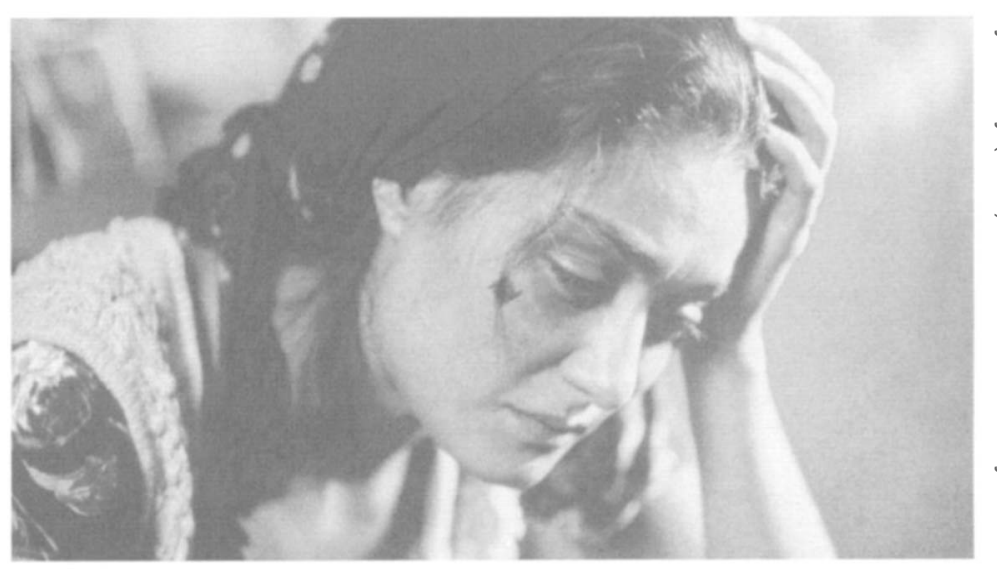


32 Hamid Dabashi, Close-Up Iranian Cinema: Past, Present and Future (London: Verso, 2001).
At several points during the monologue, the unity between the voice and the image is interrupted when Meryem stops talking and just cries, but we continue to hear her voice over the image. Then, after a cut, we see her talking again in another medium closeup shot taken from a different angle.

Needless to say, such an interruption creates a disorienting effect on the audience. Creating a distance between the voice and the body, it takes attention away from the content of the things being said to the externality of discourse itself. The question is no longer what she is saying, but how she is positioned in relation to the discourse to which she gives voice. Confession is no longer what it is normally taken to mean, that is, the revelation of truth out of the body. Contrary to the conventional understanding of speech as an indicator of self-presence and self-expression, in Meryem's monologue speech does not naturally come out of the body, but appears to be an alien presence occupying the body.

The films by Ceylan and Demirkubuz illustrate speech situations in which the subject is alienated from the meanings produced by her/his own voice. The authenticity of speech is destroyed in the sense that it no longer testifies to the inner truth of the subject producing it. Voice, in other words, can no longer be taken as a reflection of the inner truth of the subject. The distance between the voice and the body designates a problem of belonging and identity in the sense that the voice is no longer understood as an expression of something coming from within the subject, but is external to it. In this way, the films expose the compulsory as well as the performative side of belonging.

\section{Conclusion}

Commenting on recent Iranian cinema, Hamid Dabashi observes that those Iranian films popular inside the country often address timely issues, whereas the internationally acclaimed films by Iranian directors such as Abbas Kiarostami and Mohsen Makmalbaf tend to be preoccupied with more abstract and philosophical problems. ${ }^{32}$ On the basis of this observation, Dabashi reassesses the relationship between film and politics and argues that the fact that popular Iranian films address timely issues does not necessarily make them more political. 'By virtue of being timely, they are limited in their ability to imagine things otherwise than they are. They are too factually realistic to be effectively real. They are trapped in the surface of the real and can never bypass the immediacy of experience. ${ }^{33}$ By not being timely, according to Dabashi, the films by internationally acclaimed Iranian directors are much more relevant. Following a similar line of argument, I would like to suggest that in spite of their ostensibly non-political content, the films by Ceylan and Demirkubuz have much political relevance because of their relentless interrogation of the question of 'belonging'. Popular nostalgia films of the new Turkish cinema, 
34 Slavoj Zižek, The Plague of Fantasies (New York, NY: Verso. 1997). p. 75 . focusing on situations where 'home' is threatened from outside, end up rescuing an imaginary sense of 'home' as a site of integrity and virtue. Instead of yearning for a smooth sense of belonging, the cinemas of Ceylan and Demirkubuz direct attention to situations where home is challenged from within and expose the paradoxical side of 'belonging'. 'Every belonging to a society', Slavoj Žižek writes, 'involves a paradoxical point at which the subject is ordered to embrace freely, as the result of his choice, what is anyway imposed on him (we must all love our country, our parents ... ) ' ${ }^{34}$ In post-1980 Turkish society, where hackneyed nationalist discourses accompany aggressive neoliberal policies, Ceylan and Demirkubuz disclose that what appears to be natural and voluntary in relation to belonging is indeed compulsory and performative. The politics of their films is shaped around the suggestion that having an authentic, self-same voice expressing the inner truth of the subject is a myth, just like the fantasy of having a smooth sense of belonging to a home, community and homeland. 